\begin{tabular}{|c|c|c|}
\hline & Int.J.Curr.Microbiol.App.Sci (2021) 10(10): 237-243 & \\
\hline EXCELLENT & $\begin{array}{l}\text { International Journal of Current Microbiology and Applied Sciences } \\
\text { ISSN: 2319-7706 Volume } 10 \text { Number } \mathbf{1 0}(\mathbf{2 0 2 1 )} \\
\text { Journal homepage: http://www.ijcmas.com }\end{array}$ & $\begin{array}{l}9 \\
39\end{array}$ \\
\hline PUBLISHERS & & www:ijcmas.com \\
\hline
\end{tabular}

\title{
Good Agricultural Practices Followed by Awardee Farmers of Department of Agriculture Development and Farmers Welfare in Southern Kerala
}

\author{
R. S. Reshma $^{1 *}$ and G. S. Sreedaya ${ }^{2}$ \\ Department of Agricultural Extension, College of Agriculture, Vellayani, \\ Kerala Agricultural University, Thrissur - 680656, India \\ *Corresponding author
}

\begin{tabular}{|l|}
\hline Ke y w o r d s \\
$\begin{array}{l}\text { Awardee farmers, } \\
\text { good agricultural } \\
\text { practices, neem oil } \\
\text { garlic emulsion, } \\
\text { aphids }\end{array}$ \\
\hline Article Info \\
\hline $\begin{array}{l}\text { Accepted: } \\
\text { 10 September } 2021 \\
\text { Available Online: } \\
\text { 10 October } 2021\end{array}$ \\
\hline
\end{tabular}

A B S T R A C T
This research study aimed to identify good agricultural practices followed by the awardee farmers of Thiruvananthapuram and Pathanamthitta districts of Kerala. Altogether, 70 awardee farmers, 35 each from the two districts constituted the sample. This research was to analyze the main good agricultural practices followed by awardee farmers in major crops of Kerala viz. coconut, rice, banana and vegetables. The major constraints faced by these farmers and the strategies to overcome it were also studied in this work. The results showed that majority of the awardee farmers followed good agricultural practices like application of a mixture of sand, salt and ash in the pit before transplanting of coconut, soaking of seeds in fresh water in jute sacks for one day and keeping wet seeds for three days for germination in the case of rice, covering of banana bunches with dried banana leaves to increase bunch size and spraying neem oil -garlic emulsion $(2 \%)$ to control aphids of chilli. The main constraint faced by the awardee farmers was pest and wild animals attack.

\section{Introduction}

According to FAO (2003), Good agricultural practices are a set of principles to be applied to on-farm production and post-production processes, resulting in safe and balanced agricultural food and non-food products, taking into account economic, social and environmental sustainability. These practices aimed to earn a better profit in addition to maintain ecological balance. GAP in addition to improving the yield and quality of the products, also has environmental and social dimensions. Implementation of GAP would promote optimum utilization of water resources such as pesticides, fertilizers, water and eco-friendly agriculture. Its social dimension would be to protect the agricultural 
workers' health from improper use of chemicals and pesticides. The progressive farmers all over the world are expected to promote such good agricultural practices for the benefit of the sustainable agricultural and environmental development.

Kerala a small State, accounts only 1.18 per cent of the total land area of India and accommodates 3.1 per cent of the Indian population. The total land area is $38,863 \mathrm{Km}^{2}$ and has a population density of 859 people per sq $\mathrm{km}$. Demand for agriculture is increasing rapidly with population growth and per capita income and at the same time lot of initiatives are being implemented from Government and Non government organization for a sustainable agricultural development. A farmer who produced more was considered successful in earlier times. Unlike earlier times, a farmer who obtains higher productivity from his fields, who uses resources effectively and sustainably, markets his produce efficiently and can maintain quality in line with national and international standards is considered as a successful farmer (Vimalraj, 2010).

There should be enough recognition and rewards to the farmers to create interest in them for good agricultural practices and improve the quality of the produce. Therefore Government of Kerala has introduced the awards viz. K Viswanathan (Mithranikethan) Memorial Nelkathir award, Karshakothama award, Karshakathilakam award, Kerakesari award etc. to prompt and inspire the progressive farmers from the state. These awardee farmers vary from other farmers in certain ways such as the utilization of resources, marketing strategies, adoption of advanced technologies, etc. (Kale et al., 2018). The differences may be due to varied knowledge levels, skills possessed and differences in certain psychological attributes. These achiever farmers have become inspirational to fellow farmers by earning substantially from their lands due to many factors especially in the utilization of available opportunities, the adoption of latest technologies, good agricultural practices developed through indigenous knowledge etc. The present study is aimed at identifying the good agricultural practices followed by the awardee farmers of the state of Kerala.

\section{Materials and Methods}

Thiruvananthapuram and Pathanamthitta were selected as the location for the study of awardee farmers. The study was mainly focused on the awardee farmers cultivating major crops like coconut, rice, banana and vegetables in an integrated manner. As the number of these farmers were relatively more in Thiruvananthapuram and Pathanamthitta districts, these two districts were selected. Thirty five awardee farmers nominated for state awards from Thiruvananthapuram and Pathanamthitta, during the period 2014-18 were selected in consultation with Principal Agricultural Officers and other officials of Department of Agriculture Development and Farmers' Welfare, making the total sample size of respondents 70. Ex-post- facto research design was used for the study because there was no scope for manipulation of any variables under study.

Good agricultural practices refer to the onfarm ecofriendly practices, other than package of practices recommendations of Kerala Agricultural University (KAU, 2016), adopted by the farmers to increase the yield. An open ended questionnaire was prepared to document the good agricultural practices followed by awardee farmers in major crops like coconut, rice, banana and vegetables (vegetable cowpea, solanaceous vegetables and cucurbitaceous vegetables) and it is expressed in terms of frequency and percentage. 
Constraints faced by the awardee farmers were enlisted through review of literature and pilot study. These were ranked using Garrett ranking technique. The main advantage of this technique is that constraints were arranged and ranked on the basis of the importance from the view point of respondents.

Garrett's formula for converting ranks into percent was given by,

$100(\mathrm{Rij}-0.5)$

$\mathrm{Nj}$

Where $\mathrm{Rij}=$ Rank given for the $\mathrm{i}^{\text {th }}$ variable by the $\mathrm{j}^{\text {th }}$ respondent

$\mathrm{Nj}=$ Number of variables ranked by the $\mathrm{j}^{\text {th }}$ respondent.

\section{Results and Discussion}

\section{Documentation of good agricultural} practices in coconut

Table 1 shows that 92.8 per cent of awardee farmers applied mixture of sand, salt and ash in the coconut pit before transplanting. (The result is in line with the finding of Preethu and Sreedaya (2017) who reported that application of soil ameliorants is the fast moving technology in coconut). The reason is that sand improves the texture of soil and facilitates easy rooting of seedlings. Salt and ash have germicidal property. Ash controls termite attack effectively.

In order to control bud rot, 70 per cent of the awardee farmers applied salt and ash mixture in the crown. About 61.43 per cent of them followed burial of banana pseudostem in the coconut pit because well dried pieces of pseudostem attract pests. 52.86 per cent of them practiced deposition of palm waste at the base of the trunk which helps to prevent loss of fertile top soil through run off and to decrease soil temperature.

\section{Documentation of good agricultural practices in rice}

Table 2 shows that majority of the awardee farmers $(81.43 \%)$ followed soaking of rice seeds in fresh water in jute sacks for one day and keeping wet seeds for 3 days for better germination. In the case of plant protection, 72.86 per cent of them practiced clipping of seedlings leaf tips prior to transplantation to destroy the egg masses of stem borer. In order to attract and kill the moths of leaf folder, stem borer, Brown Plant Hopper, gall fly and rice bug, 70 per cent of them installed light traps in the field. More than half $(68.57 \%)$ of the awardee farmers follow application of neem oil $(2 \%)$ or neem cake extract $(10 \%)$ to control rice thrips. To reduce rice blast in the nursery, they apply $100 \mathrm{~g} / \mathrm{m}^{2}$ rice hull ash. About 51.43 per cent of them grow azolla as green manure before transplanting as it provides nitrogen to growing rice and suppresses weeds.

\section{Documentation of good agricultural practices in banana}

From table 3, it is clear that the most commonly followed good agricultural practices by awardee farmers were covering of banana bunches with dried banana leaves to increase bunch size $(85.71 \%)$, smearing of cowdung on banana sucker for speedy bud initiation (82.86\%) (Thasneem, 2016), smearing of cowdung and pseudomonas mixture on sucker followed by sprinkling of water thrice a week (78.57\%), application of salt in the leaf axils of banana to control snails $(72.86 \%)$, inserting of bar soap into the bore holes of pseudostem weevil to reduce its attack $(70.00 \%)$ and cutting and burning of infected banana leaves for controlling sigatoka disease (64.28\%). 
Table.1 Documentation of good agricultural practices in coconut

\begin{tabular}{|c|c|c|c|}
\hline SI. No. & Practices in coconut & F (N=70) & Percentage \\
\hline 1. & $\begin{array}{c}\text { Application of a mixture of sand, salt and ash in the } \\
\text { pit before transplanting }\end{array}$ & 65 & 92.8 \\
\hline 2. & Application of salt and ash mixture in the crown & 49 & 70 \\
\hline $\mathbf{3 .}$ & Burial of pseudostem of banana in the pit & 43 & 61.43 \\
\hline $\mathbf{4 .}$ & Shading the seedlings with coconut leaves & 39 & 55.71 \\
\hline $\mathbf{5 .}$ & Deposition of palm waste at the base of the trunk & 37 & 52.86 \\
\hline
\end{tabular}

Table.2 Documentation of good agricultural practices in rice

\begin{tabular}{|c|c|c|c|}
\hline Sl. No. & Practices in rice & F (N=70) & \% \\
\hline $\mathbf{1 .}$ & $\begin{array}{c}\text { Soaking of seeds in fresh water in jute sacks for one } \\
\text { day and keeping wet seeds for 3 days }\end{array}$ & 57 & 81.43 \\
\hline $\mathbf{2 .}$ & $\begin{array}{c}\text { Clipping of the seedlings leaf tips prior to } \\
\text { transplantation }\end{array}$ & 51 & 72.86 \\
\hline $\mathbf{3 .}$ & Installation of light traps in the field & 49 \\
\hline $\mathbf{4 .}$ & $\begin{array}{c}\text { Application of } 2 \% \text { neem oil or } 10 \% \text { neem cake } \\
\text { extract can control rice thrips }\end{array}$ & 48 & 52.86 \\
\hline $\mathbf{5 .}$ & $\begin{array}{c}\text { Application of rice hull ash @ } 100 \mathrm{~g} / \mathrm{m}^{2} \text { to reduce } \\
\text { the incidence of blast in the nursery }\end{array}$ & 37 & 51.43 \\
\hline 6. & $\begin{array}{c}\text { Growing azolla as green manure before } \\
\text { transplanting }\end{array}$ & 36 & 70 \\
\hline
\end{tabular}

Table.3 Documentation of good agricultural practices in banana

\begin{tabular}{|c|c|c|c|}
\hline Sl. No. & Practices in banana & Frequency $(\mathrm{N}=70)$ & Percentage \\
\hline 1. & $\begin{array}{l}\text { Covering of banana bunches with dried } \\
\text { banana leaves }\end{array}$ & 60 & 85.71 \\
\hline 2. & $\begin{array}{l}\text { Smearing of cowdung on banana sucker for } \\
\text { speedy bud initiation }\end{array}$ & 58 & 82.86 \\
\hline 3. & $\begin{array}{l}\text { Smearing of cowdung and pseudomonas } \\
\text { mixture on sucker followed by sprinkling of } \\
\text { water thrice a week }\end{array}$ & 55 & 78.57 \\
\hline 4. & $\begin{array}{l}\text { Application of salt in the leaf axils of } \\
\text { banana to control snails }\end{array}$ & 51 & 72.86 \\
\hline 5. & $\begin{array}{l}\text { Inserting of bar soap into the bore holes of } \\
\text { pseudostem weevil to reduce its attack }\end{array}$ & 49 & 70 \\
\hline 6. & $\begin{array}{l}\text { Cutting and burning of infected banana } \\
\text { leaves for controlling sigatoka disease }\end{array}$ & 45 & 64.28 \\
\hline
\end{tabular}


Table.4 Documentation of good agricultural practices in vegetables

\begin{tabular}{|c|c|c|c|}
\hline Sl. No. & Practices in vegetables & $\mathrm{F}(\mathrm{N}=70)$ & $\%$ \\
\hline 1. & $\begin{array}{c}\text { Spraying of neem oil -garlic emulsion (2\%) to } \\
\text { control aphids of chilli }\end{array}$ & 63 & 90 \\
\hline 2. & $\begin{array}{l}\text { Spraying of soap-garlic-castor oil emulsion ( } 2 \%) \text { to } \\
\text { control epilachna beetle of brinjal }\end{array}$ & 51 & 72.86 \\
\hline 3. & $\begin{array}{l}\text { Application of neem seed kernel extract } 5 \% \text { against } \\
\text { pod borers of cowpea }\end{array}$ & 49 & 70 \\
\hline 4. & $\begin{array}{c}\text { Growing of marigold as a border crop in brinjal to } \\
\text { control fruit borers }\end{array}$ & 45 & 64.29 \\
\hline 5. & $\begin{array}{l}\text { Spraying of boiled leaves of neem }(4-5 \mathrm{~kg} \text { in } 10 \mathrm{~L} \\
\text { water) for 2-3 times in a season safeguards the crops } \\
\text { from major pests especially Helicoverpa at larval } \\
\text { stage. }\end{array}$ & 43 & 61.43 \\
\hline 6. & $\begin{array}{l}\text { Cultivation of vegetables in polyhouse to reduce the } \\
\text { pest attack }\end{array}$ & 16 & 22.86 \\
\hline
\end{tabular}

Table.5 Constraints faced by the farmers at farm level

\begin{tabular}{|c|c|c|c|}
\hline Sl. No. & Constraints & $\begin{array}{c}\text { Garrett } \\
\text { score }\end{array}$ & Rank \\
\hline 1. & Pest attack & 73.58 & 1 \\
\hline 2. & Seasonal variations & 71.48 & 2 \\
\hline 3. & Fall in market price & 68.93 & 3 \\
\hline 4. & Cumbersome process in getting loan sanctioned & 53.36 & 4 \\
\hline 5. & Lack of availability of credit facilities on time & 53.18 & 5 \\
\hline 6. & Unavailability of timely and skilled labour & 43.28 & 6 \\
\hline 7. & Absence of good marketing avenues/facilities & 39.37 & 7 \\
\hline
\end{tabular}

Documentation of good agricultural practices in vegetables

Table 4. shows that the most commonly used good agricultural practices in vegetables were spraying of neem oil -garlic emulsion $(2 \%)$ to control aphids of chilli $(90.00 \%)$ followed by spraying of soap-garlic-castor oil emulsion (2\%) to control epilachna beetle of brinjal (72.86\%), application of neem seed kernel extract $5 \%$ against pod borers of cowpea (70\%), growing of marigold as a border crop in brinjal to control fruit borers (64.29\%), spraying of boiled leaves of neem $(4-5 \mathrm{~kg}$ in $10 \mathrm{~L}$ water) for 2-3 times in a season safeguards the crops from major pests especially Helicoverpa at larval stage (61.43 $\%)$ and cultivation of vegetables in polyhouse to reduce the pest attack $(22.86 \%)$.

\section{Other innovative technologies and enterprises followed by awardee farmers}

Awardee farmers use machines like tractors, tillers, seed drills, rotavators etc. apart from human labour used by other farmers. Tractors and tillers help them in ploughing, tilling and clearing bushes. Seed drills facilitate them in sowing to a specific depth. They use improved and hybrid varieties rather than local varieties 
to get more yield. They test the soil periodically. Soil testing is needed to know about the nutrient status of the soil. If the soil is found to be deficient or excess in any of the nutrients, Integrated Nutrient Management (INM) is followed. When the ordinary farmers adopt any one of the cultural, physical, biological or chemical methods for pest management, awardee farmers go for Integrated Pest Management (IPM), incorporating all these methods. It is a method which is used to solve pest problems without or at low level of risk to the people and environment. Pesticides are only used according to standard guidelines and treatment is done with a goal of removing only the target organisms. In the case of irrigation, awardee farmers use drip, wick or sprinkler irrigation which improves the water use efficiency.

Most of them possess vermicomposting and Trichoderma enrichment unit in their farm. Subsidiary enterprises like mushroom cultivation, dairy, poultry etc. helps them in increasing their income level.

\section{Constraints faced by the awardee farmers.}

From table 5, the major constraints faced by the awardee farmers were pest attack (especially wild animal attack), seasonal variations, fall in market price, cumbersome process in getting loan sanctioned, lack of availability of credit facilities on time, unavailability of timely and skilled labour and absence of good marketing avenues/facilities

\section{Strategies to overcome the constraints}

There should be a proper pest surveillance and crop health management system to identify and control the pests and diseases. Suitable measures like solar fencing should be provided to the farmers to get rid of wild animal attack. To control seasonal variations, vegetables can be cultivated in poly house.
Government should increase the procurement price of agricultural produces to support farmers. Banks should provide adequate credit facilities to farmers on time and the moratorium period should be extended for the agricultural loans taken by the farmers.

Government can organize awareness programmes about the need of agriculture which can attract youth towards agriculture thereby reduce the problem of unavailability of labour.

From the study it is clear that the awardee farmers practiced not only the traditional and recommended practices, but also innovative technologies in production, protection, value addition, storage and in marketing. It can be concluded that, other farmers should also follow this holistic approach adopted by these awardee farmers because the future of agriculture depends on such an inevitable convergence.

\section{References}

FAO [Food and Agriculture Organization] (2003). Incentives for the adoption of good agricultural practices: Background paper for the FAO expert consultation on a good agricultural practice approach.10-12 November 2003, Rome. [On-line]. Available:http://www.fao.org/tempref/ docrep/fao/010/ag854e/ag854e00.pdf[ 02 March 2021].

GOK [Government of Kerala] (2000). Awards [On-line] Available: https://keralaagriculture.gov.in/awards/ [16-04- 2021].

Kale, N. D., Kshatriya, A. M., Kausadikar, H. H., and Desai, A. N. (2018). Relationship between personal, socioeconomic characteristics and cropping pattern of the awardee farmers. Int. J. Curr. Microbiol. App. Sci. 6: 1538- 
1544.

KAU [Kerala Agricultural University] (2016). Package of Practices Recommendations, (15 ${ }^{\text {th }}$ Ed.), Kerala Agricultural University.

Mergewar, A. R., Deshmukh, P. R., and Deshmukh, N. D. (2017). Study of relationship between profile of awardee farmer with cropping pattern followed by awardee farmers in Marathwada region. Agric. Update. 12(4): 653-656.

Paul, P. K. and Sreedaya, G. S.(2017). Perception of farmers about LEADS in Kollam and Palakkad district: A comparative analysis, M.Sc.(Ag.) Thesis, Kerala Agricultural University, Thrissur.118p.

Thasneem, S. (2016). Technology utilization of banana in Thiruvananthapuram district. M.Sc. (Ag.) thesis, Kerala Agricultural University, Thrissur, $120 \mathrm{p}$.

Vimalraj, G. (2010). An analytical study of best practices and competencies of award winning agripreneurs of Tamil Nadu. M. Sc. (Ag.) thesis, Indian Agricultural Research Institute, New Delhi.133p.

\section{How to cite this article:}

Reshma, R. S. and Sreedaya, G. S. 2021. Good Agricultural Practices Followed by Awardee Farmers of Department of Agriculture Development and Farmers Welfare in Southern Kerala. Int.J.Curr.Microbiol.App.Sci. 10(10): 237-243. doi: https://doi.org/10.20546/ijcmas.2021.1010.028 